\title{
How to govern the city? Polish debates about urban policy during the First World War*
}

\section{STREsZCZenie}

\section{Jak sprawować rządy w mieście? Polskie debaty o polityce miejskiej w trakcie I wojny światowej}

D rzedmiotem artykułu sa debaty na temat polityki miejskiej na obszarze okupowanych ziem polskich w trakcie I wojny światowej. Ten czteroletni okres czasu oznaczal $z$ jednej strony olbrzymi kryzys ekonomiczny i humanitarny w miastach Królestwa Polskiego, z drugiej zaś możliwość samoorganizacji społeczeństwa poprzez organizację komitetów obywatelskich, a później także wybory do rad miejskich i kampanię wyborcze w największych miastach Królestwa Polskiego, Warszawie i Łodzi. W artykule analizie poddano dyskurs miejski $z$ tego okresu publikowany na łamach prasy oraz w postaci specjalistycznych publikacji o tematyce miejskiej, ze szczególnym uwzględnieniem kwestii sporu o optymalny kształt miejskiej polityki, zasięg działania samorządu miejskiego i właściwy kierunek rozwoju miast w przededniu odzyskania niepodległości przez Polskę oraz inne państwa Europy Środkowej i Wschodniej.

Słowa kluczowe: I wojna światowa - warunki życia, Królestwo Polskie, komitety obywatelskie, socjalizm municypalny, samorzad miejski, wybory samorzadowe

\section{ABSTRACT}

$\mathrm{T}$ he subject of the article are Polish debates on urban policy during the First World War. This four-year period of time was, on the one hand, a huge economic and humanitarian crisis in the cities of the Kingdom of Poland. On the

* This paper presents results of research project financed by the (Polish) National Science Centre contracted as UMO-2014/15/D/HS3/00411. 
other hand, society achieved the possibility of self-organization through the organization of civic committees, but later also by taking part in municipal elections to councils established in the areas occupied by Central Powers and political campaigns in Warsaw or Łódź - two biggest and the most important cities in the Kingdom of Poland. Author analyzes the most representative aspects of an urban discourse from that period (including press and specialist literature published in Warsaw and Łódź), with particular emphasis on the issue of the dispute about the optimal shape of urban policy, scope of the self-government and the proper direction of urban development on the eve of Poland's regaining independence and other Central and Eastern European countries. although the issue of municipal self-government appeared in almost every newspaper at that time, the new framework for city politics in Poland emerged in discussions between specialists and authors with the biggest knowledge and longtime experience in writing about this subject.

Keywords: Living conditions during the World War I, Kingdom of Poland, citizen's committees, urban self-government, municipal socialism, urban elections

\section{Introduction}

7 he Great War, which destroyed the Belle Époque world, was undoubtedly a new situation for all spheres of society, which had to cope with extraordinary problems in almost all aspects of life: fear, death, hunger, homelessness and many others. In recent years both wartime urban life and urban politics and institutions have become interesting topics for scholars interested in both Western and Central Eastern European contexts. Jay Winter and Jean-Louis Robert examined the experience of capital cities between 1914 and 1919 ${ }^{1}$. The journal Cahiers Bruxellois Brusselse Cahiers published a special issue about cities at war, with interesting papers covering Brussels, Lille, London, Petrograd, Berlin, Hamburg and Vienna ${ }^{2}$. Although a Western-oriented perspective still dominates in the international historiography, fresh interesting studies about Eastern European experiences of

1 J. Winter, J-L. Robert, Capital Cities at War: Paris, London, Berlin, 1914 1919. A Cultural History, Cambridge 2007.

${ }^{2}$ G. Pluvinage, Brussels on German Time, "Cahiers Bruxellois - Brusselse Cahiers" 2014, vol. XLVI, No. 1E, pp. 15-38; R. V and e bu s s che, Lille in German Hands, "Cahiers Bruxellois - Brusselse Cahiers" 2014, vol. XLVI, No. 1E, pp. 105119; J. White, London in the First World War, ibidem, pp. 139-157; A. Scriba, Berlin in the 1914-1918 War, ibidem, pp. 173-188; C. Strupp, Hamburg in the First World War, ibidem, pp. 189-210. 
the Great War have been published over the last decade ${ }^{3}$. One of the most iconic is Robert E. Blobaum's recent book about Warsaw during the Great War ${ }^{4}$. Blobaum argued that the Great War was a "minor apocalypse" for the Polish capital, which had to cope with enormous poverty, hunger, epidemics caused by the wartime shortages and the ravages of occupying powers. The logic behind the German occupation of the Kingdom of Poland was recently revealed by Jesse Kauffman ${ }^{5}$. Last but not least are the studies by Włodzimierz Borodziej, Maciej Górny ${ }^{6}$, Jan Lewandowski $^{7}$, Katarzyna Sierakowska ${ }^{8}$, Andrzej Chwalba ${ }^{9}$ and others ${ }^{10}-$ published in Polish.

Russian Poland, which suffered directly from war in 1914 and 1915 and later became occupied by Austria-Hungary and Germany, was indeed an area of field testing for the whole region of Central East Europe. The urban experience of war and occupation started there with the cruel destruction of the city of Kalisz in August 1914 and finished at the beginning of 1917 when municipal councils were introduced in Warsaw, Łódź and other cities - among many other national institutions which symbolized the emergence of the independent Polish state. What should be stressed here, in contrast to internal regions of Russia, is that Polish towns and cities were deprived of any form of urban self-government before the war and run directly by the government (the so-called "magistrats" were indeed the lowest level of government administration).

${ }^{3}$ See: K. Petrone, The Great War in Russian Memory, Bloomington-Indianapolis 2011, pp. 127-165; J.A. S a n b or n, Imperial Apocalypse. The Great War and the Destruction of the Russian Empire, Oxford 2014, pp. 39-63.

${ }^{4}$ R.E. Blobaum, A Minor Apocalypse: Warsaw during the First World War, New York 2017.

5 J. Kauffman, Elusive Alliance: The German Occupation of Poland in World War I, Cambridge, Mass. 2015.

${ }^{6}$ W. Borodziej, M. Górny, Nasza wojna, vol. I (Imperia 1912-1916), Warszawa 2014.

7 J. Lew andowski, Okupacja austriacka w Królestwie Polskim (1914-1918), “Dzieje Najnowsze” 1998, vol. XXX, pp. 29-42.

${ }^{8}$ K. Sierakowska, Śmierć, wygnanie, głów $w$ dokumentach osobistych. Ziemie polskie w latach Wielkiej Wojny 1914-1918, Warszawa 2015.

9 A. Chwalba, Wielka Wojna Polaków 1914-1918, Warszawa 2018.

10 Imperia, Narody $i$ Społeczeństwa Europy Wschodniej i Środkowej, na progu Pierwszej Wojny Światowej, ed. A. Nowak, Warszawa 2016; Pierwsza niemiecka okupacja. Królestwo Polskie i kresy wschodnie pod okupacja mocarstw centralnych 1914-1918, ed. G. Kucharczyk, Warszawa 2019. 
Therefore, in the case of Russian Poland the war was also a test for local communities, which had to take responsibility for their cities.

As a result, debates about the urban governance and urban policy that took place during the Great War were focused on both theoretical and practical aspects. Journalists and professionals not only criticized the former tsarist administration, but also had to answer the questions about the nature of urban policy, the way of organizing schools, healthcare, building housing for workers etc. Their task was to keep the spirit of society and answer the question of how to govern the city, when war was going on all around. I believe it is worth examining this discourse to try to find some broader conclusions about Polish urban war experiences and their relationship with the history of the region as a whole. Therefore, in this paper I present some general remarks about the political, economic and social condition of cities in the Kingdom of Poland. After which I analyze the most significant topics in the Warsaw's and Łódź's press discourse from the beginning of the war to the municipal elections. For Polish cities wartime elections were an exit from an extraordinary measures, even if their economic and social conditions remained critical even after the war ${ }^{11}$. Finally, I provide some general remarks on the Polish and Central European urban experience of the first stage of the Great War and its impact on urban policy in the following years.

I am aware that this approach to so huge topic has some limitations. Some important issues like postwar reconstruction or the enlargement of Warsaw and Lódź done by the German occupants are not being considered here ${ }^{12}$. Definitely it would be the great idea for some historian to write the comprehensive book about all aspects of the urban policy and economy in the Kingdom of Poland between 1914 and 1918 .

\section{Unfinished reform, unsolved problems and serious conflicts}

As noted above, urban self-government did not exist in the Kingdom of Poland prior to World War I. Although the Kingdom of Poland experienced rapid urbanization and industrialization during the

${ }^{11}$ R.E. Blobaum, op. cit., p. 244.

12 See: Reconstruction and Modernization of Historic Towns in Europe in the First Half of the Twentieth Century: Nation, Politics, Society, eds I. Barańska, M. Górzyński, Kalisz 2016. 
second half of the $19^{\text {th }}$ century ${ }^{13}$, after the failed January Insurrection of 1863 urban self-government was abandoned. Urban administration became a matter for state government and "magistrats" local executive boards comprised of mayors (presidents in bigger cities) and a number of nominated councilors ${ }^{14}$. These authorities, however, had very limited powers - almost all important decisions needed the approval of the governors, if not directly from St. Petersburg. As a result, a rational urban policy in the Kingdom of Poland became almost impossible for the next 50 years. The logic of this system was indeed, very "policing" and focused on eliminating potential disorder. Russian authorities were, first of all, afraid of the supposed political importance of urban self-governance in Poland. In their logic, direct governmental administration was much more secure than any form of Polish autonomy ${ }^{15}$.

Under these circumstances, Polish cities became backward and neglected. As Robert Blobaum argued "As subjects of the Russian tsar before the war, Varsovians had neither rights nor privileges when it came to relief or public assistance. [...] Warsaw was among those cities, denied as it was institutions of municipal self-government that, for example, had capably funded and administered relief for the poor in Moscow. Instead, Warsaw's nonelected city administration shared the belief of the vast majority of local governments that the existence of private charitable organizations, the major source of institutional assistance to the poor in the empire before the war, "absolved them from any responsibility for relief beyond a modest subsidy". Moreover, the development of private charitable organizations and other kinds of voluntary associations in Warsaw and in the Polish Kingdom as a whole was slow in coming"16.

${ }^{13}$ M. Nietyks za, Rozwój miast i aglomeracji miejsko-przemysłowych w Królestwie Polskim: 1865-1914, Warszawa 1986.

${ }^{14}$ Ibidem, pp. 19-26.

15 T.R. Weeks, Nationality and Municipality: Reforming City Government in the Kingdom of Poland, 1904-1915, "Russian History" 1994, No. 1, pp. 23-47; K. Śmiech ow s ki, Searching for the Better City: Urban Discourse during the Revolution of 1905 in the Kingdom of Poland, "Praktyka Teoretyczna" 2014, No. 3(13), https://pressto.amu.edu.pl/index.php/prt/article/view/510/422 (accessed: 18 IX 2021); M. Rolf, Imperiale Herrschaft im Weichselland: das Königreich Polen im Russischen Imperium (1864-1915), Berlin-Muenchen-Boston 2015.

16 R.E. Blobaum, op. cit., pp. 101-102. 
Public opinion strongly believed that urban self-government would solve all problems behind the underdevelopment of urban infrastructure or the lack of important institutions ${ }^{17}$. The demand for urban self-government, even if it was too idealized, became an important part of the Polish political agenda after the revolution of 1905. However, the process of preparing the reform, initiated in 1905, was very slow and embroiled. Drafts of new laws were considered in the Duma from 1910 but became stuck in a political deadlock without chances to satisfy any demands ${ }^{18}$. Moreover, the official project was very disappointing for Poles. Elections were intended to be based on the curial system, which guaranteed seats in planned council for Russians even if their number among the population of Polish cities or towns was very small. On the other hand, the representation of Jews, who were the second biggest group of the population in Warsaw or Łódź and formed the majority in a large number of smaller towns, was limited. During the legislative process in the Duma and Council of State, some Polish principia like the language of planned councils were also questioned. As a result, the planned reforms lost almost all support in the society of the Kingdom of Poland ${ }^{19}$.

Although dreams about elected city councils did not materialize before World War I, the urban intelligentsia was generally prepared to take part in the planned councils. During the 1905 revolution the opening of Polish private schools, legal trade unions or cultural and educational associations were facilitated. As a result, public life in the Kingdom of Poland flourished despite general political disarray across the whole of the Russian Empire. The most important of the newly-created organizations, like Polska Macierz Szkolna (Polish School Society), Towarzystwo Kursów Naukowych (Association of Educational Courses) developed an institutional framework that managed to replace the administration in many aspects of urban life ${ }^{20}$. Additionally, traditional philanthropic organizations as well as some professional associations (like Warszawskie

${ }^{17}$ K. Śmiechowski, Kwestie miejskie. Dyskusja o problemach i przyszłości miast $w$ Królestwie Polskim 1905-1915, Łódź 2020, pp. 141-178.

${ }^{18}$ See: M. Wi erzchowski, Sprawy polskie w III i IV Dumie Państwowej, Warszawa 1966.

19 T.R. W e e k s, op. cit.

${ }^{20}$ H. Kiepurska, Warszawa $w$ rewolucji 1905-1907, Warszawa 1974; W.L. Ka rw a c ki, Łódź w latach rewolucji 1905-1907, Łódź 1975. 
Towarzystwo Higieniczne - Warsaw Hygienic Association) or even individual professionals made huge advances on urban issues ${ }^{21}$. People like Adolf Suligowski, author of many works about urban policy, Władysław Dobrzyński, pioneer of the idea of the "garden city" in Poland or the hygienist Józef Polak strongly believed that they knew how to reform their cities, however they lacked any possibilities to prove it except through necessary and ambivalent contacts with the Russian administration.

The decade between 1905 and 1914 changed urban reality in the Kingdom of Poland in an irreversible way ${ }^{22}$. One of the most iconic features of this new reality was the conflict between Poles and Jews, which erupted after 1905 and reached its apogee in the years following the Great War ${ }^{23}$. Escalated by the powerful National Democratic Party ("Endecja") with the support of some catholic organizations and their press ${ }^{24}$, it escalated when Jewish voters contributed to the defeat of Roman Dmowski, the leader of "Endecja", in the 1912 Duma elections. For right-wing politicians, the call for an economic boycott of Jews in the Kingdom of Poland was indeed a very useful political tool. It enabled them to transform

${ }^{21}$ A. Eu pien ko, Some Remarks on the Birth of Modern City Planning in the Polish Territories (1850-1914): The Impact of the Hygienic Movement, "Mesto a Dejiny" 2016, No. 2, pp. 18-34.

${ }^{22}$ R.E. Blobaum, Rewolucja: Russian Poland 1904-1907, Ithaca 1995; T. Stegn er, Rewolucja w opinii środowisk liberalnych Królestwa Polskiego w latach 1905-1907, [in:] Rewolucja 1905-1907 w Królestwie Polskim i w Rosji, Kielce 2005, pp. 21-43; S. Ury, Barricades and Banners. The Revolution of 1905 and the Transformation of Warsaw Jewry, Stanford, Ca 2012; W. Marzec, K. S mi echows ki, Pathogenesis of the Polish Public Sphere. The Intelligentsia and Popular Unrest during and after the 1905 Revolution, "Polish Sociological Review" 2016, No. 4, pp. 437-457; W. Marze c, Rebelia i reakcja. Rewolucja 1905 roku i plebejskie doświadczenie polityczne. Horyzonty nowoczesności: teoria - literatura - kultura, Łódź-Kraków 2016.

${ }^{23}$ R.E. Blobaum, The Politics of Antisemitism in Fin-de-Siècle Warsaw, "The Journal of Modern History" 2001, vol. LXXIII, No. 2, pp. 275-306; K. Zielinns ki, Stosunki polsko-żydowskie na ziemiach Królestwa Polskiego w czasie pierwszej wojny światowej, Lublin 2010; G. Krzywi e c, Polska bez Żydów. Studia z dziejów idei, wyobrażeń $i$ praktyk antysemickich na ziemiach polskich poczatku XX wieku, Warszawa 2017.

${ }^{24}$ T.R. Weeks, Fanning the Flames: Jews in the Warsaw Press 1905-1912, "East European Jewish Affairs" 1998, vol. XXVIII, No. 2, pp. 63-81. See also: J. Nalew ajko-Kulikov, Myśli nowoczesnych Żydów. Wybory do IV Dumy, bojkot ekonomiczny $i$ stosunki polsko-żydowskie (1912-1914) w świetle warszawskiego „Hajntu”, "Kwartalnik Historii Żydów” 2016, No. 2, pp. 279-299. 
typical class conflicts into a huge mobilization of Polish groups of the urban population against their Jewish neighbors. This strategy was oriented on the future "Polonization" of cities, which was impossible without the building of a strong Polish middle class. For Dmowski and other ideologists of "Endecja", whose ideas for a national-oriented modernization went together with chauvinism and racism ${ }^{25}$, Jews in Poland were considered to be the obstacle in the development of "truly" Polish cities, which could only be solved by open conflict. This was the reason why "Endecja" supported the government in limiting the number of Jews in planned urban governments $^{26}$. It is worth adding that during the last years of peace similar actions, strengthened by official propaganda of the tsarist regime, although less aggressive than anti-Semitic biases, were directed against the significant German bourgeoisie in Łódź and minorities in other Western provinces of the Kingdom of Poland, who were perceived not only as "old" cultural and economic rivals, but also potential fifth columnists of imperial Germany ${ }^{27}$.

It can be seen therefore that the "urban question" in the Kingdom of Poland before the Great War was complicated and polarized. It needed rapid and deep reforms that the arrogant elites from St. Petersburg were not able to introduce. However, unlike in 1905, urban political life before the Great War became very ethnicized and threatened violence. In the summer of 1914 it became obvious that possible war between Russia and the Central Powers would change everything.

Urban discourse in the Kingdom of Poland during the Great War can be divided into three stages. Firstly, mostly in 1914, the debate focused on wartime rescue and the citizens committees which organized the assistance. The second stage, from March 1915 to the beginning of the occupation of the whole of the territory of Russian Poland, was a time of deep discussion about self-government, which had been unexpectedly announced by the $\operatorname{tsar}^{28}$. Finally, the last stage happened under the Austro-Hungarian and German rule in late 1916 and 1917, when municipal elections were

${ }^{25}$ G. Krzywiec, Szowinizm po polsku. Przypadek Romana Dmowskiego (1886-1905), Warszawa 2009.

26 T.R. W e eks, Nationality and Municipality...

27 The most significant anti-German pamphlet was written by Stefan Gors ki: Niemcy w Królestwie Polskim, Warszawa 1911.

${ }^{28}$ See: A. A ch matowicz, Polityka Rosji $w$ kwestii polskiej $w$ pierwszym roku Wielkiej Wojny 1914-1915, Warszawa 2003. 
held and city councils finally became established. Each of these stages requires separate analyses.

\section{Organization first}

"Citizens!

We have to fend for ourselves! Both the Citizens Guard and every good-thinking citizen should keep an eye on the public order in our city! On the command of the Guard member everyone should help Him!

Poor people! Be patient and calm. The Citizens Committee thinks about You! As far as possible, the Committee will help all, despite different nationality and religion!

Richer ones! Remember about the poorest! Side by side! Who supports the poor is helping himself.

[...] In consent and love, let us make our life normal. Once again we are calling for peace and balance" ${ }^{29}$.

This proclamation by the Citizens Committee in Lódź was published in the local press in the mid-August, 11, 1914. The Citizens Committee was formed on August 3, 1914 after the Russian administration was evacuated. It evolved from a "Council of Fourteen", formed just two days earlier and consisted of well-known inhabitants: industrialists, catholic priests, a pastor and rabbi. The leader of the Council was industrialist Alfred Biedermann. After ten days of existence the Citizens Committee was renamed Główny Komitet Obywatelski - Main Citizens Committee. The members were predominantly local bourgeois elites, industrialists and merchants ${ }^{30}$.

Probably the first citizens committee was formed in Wołomin on July 10, 1914. Warsaw's committee was established on August 1, 1914, with Polish Prince Zdzisław Lubomirski, who later became the mayor of Warsaw, as its informal leader. The same day in the governorate city of Piotrków, a committee formed of notable residents of this city was established ${ }^{31}$.

${ }^{29}$ Do mieszkańców miasta Łodzi, "Nowy Kurier Łódzki", August 11, 1914, No. 181.

${ }^{30}$ A. Stawiszyńska, Łódź w latach I wojny światowej, Oświęcim 2016, pp. 25-26.

${ }^{31}$ A. Piasta, Powstanie $i$ zarys działalności Komitetu Obywatelskiego Miasta Piotrkowa 1914-1915, "Piotrkowskie Zeszyty Historyczne" 2005, vol. V, pp. 219-233. 
By June 1915 there were 91 urban citizens committees in the Kingdom of Poland ${ }^{32}$. Their activities were coordinated by the Central Citizens Committee, established in September of 1914. This organization was not only a form of executive board for the local committees, but also an important political representation of Polish society, being made up of mostly members of "Endecja", conservatives and loyalists. However in some places it took much more time than in Warsaw or Łódź. For instance in Kielce, the committee was not formed until the end of November $1914^{33}$.

Citizens committees were an original form developed from existing forms of civil society into organizations ready to take responsibility for the whole of urban life. The social composition of these committees (formed of the most well-known or most notable persons from the local community, members of the urban bourgeoisie and intelligentsia) was generally similar to the other extraordinary committees or commissions formed by "magistrats" during important crises or natural disasters. Indeed, the war was an emergency situation. The main difference was the wide range of issues with which the new committees were faced. In theory, committees had to be accepted by and cooperate with the administration. In fact, after they were formed, Russian mayors with clerks left their cities or became indolent. As Maciej Górny and Włodzimierz Borodziej pointed out, "it was quite a sensation that such a large number of powers was granted to a "citizens committee", a social organization. [...] Russia ceded the most troublesome duties of state power in its Hinterland to Polish elites, who had been deprived of any form of self-governance before 1914"34. On the other hand, Warsaw's experience of social self-organization during the first weeks of war, was very similar to situation in Brussels before it was took by Germans ${ }^{35}$.

As "Kurier Warszawski", the biggest daily newspaper in the Kingdom of Poland announced, the Warsaw's Committee intended to take care of:

${ }^{32}$ A. Chwalba, op. cit., p. 202.

${ }_{33}$ M. Przeniosło, Komitet Obywatelski miasta Kielc 1914-1915, [in:] Z dziejów Kielc w latach 1914-1918, Kielce 2004, pp. 37-48.

${ }^{34}$ W. Borodziej, M. Górny, op. cit., pp. 233-234.

${ }^{35}$ G. Pluvinage, op. cit., p. 17. 
1) protection and distribution of essentials,

2) activation of financial measures,

3) job searching for destitute people and help for families of reservists,

4) finally, public security ${ }^{36}$.

Although the number of problems which citizens committees had to cope with was incredibly high, public opinion strongly supported them. On August 5, 1914, just five days after the Citizens Committee was formed, "Kurier Warszawski" stated: "The community of Warsaw, which showed calmness, prudence and maturity during the crucial breakthrough, has our sincere appreciation. [...] It took only 24 hours before the Committee and the women's organization which supports it were legalized and preparations had already taken a step forward. Both organizations, closely tied and coordinated, were split into many sections, according to the most important and essential needs of the moment.

[...] With appreciation, we find that everything that was possible at that moment was done. So, we strongly support the Committee and appeal to the never failing public generosity, we hope that Committee's efforts will relieve the most troubled in their suffering and will dry the tears of families who have lost bread and work" ${ }^{37}$.

After 100 days, Warsaw's Committee was praised for its efficiency. Kurjer stressed that hundreds were selflessly engaged in the work of the Committee sections: "this volunteer spirit is a hundred times better than donations in kind. Many people give over whole days to doing tasks, often difficult". Generally it was believed that "in providing help the Committee intended to make this as effective as possible" ${ }^{38}$. The scale of the problems that needed to be solved was, however, enormous. The economic situation of the Kingdom of Poland was dramatic and the Committee put a lot of effort into preserving urban funds and estates untouched ${ }^{39}$. Some problems

${ }^{36} \mathrm{Z}$ miasta. Komitet Obywatelski, "Kurier Warszawski", August 2, 1914 (special editon), No. 211.

${ }^{37}$ Praca Komitetu Obywatelskiego, "Kurier Warszawski", August 5, 1914 (morning edition), No. 214.

38100 dni pracy Komitetu Obywatelskiego, "Kurier Warszawski", November 14, 1914, No. 315.

39 Finanse magistratu, "Kurier Warszawski", August 5, 1914 (morning edition), No. 214. 
like covered bond still needed the intervention of St. Petersburg, where most of the committee's funds came from. One of the most dramatic was food and supply of goods ${ }^{40}$. Although the Russian "magistrat" was inefficient, the press still published many appeals for more activity and better cooperation with the Committee ${ }^{41}$. Another serious problem was the homelessness caused by wartime migrations ${ }^{42}$. Of course, apart from all those problems connected with war many aspects of urban life remained political. Conflict between Poles and Jews, especially in Warsaw, became serious. Some fields of interest of the Committee were an area of these disagreements and the policy of the right-wing Committee was not impartial and escalated troubles ${ }^{43}$.

Despite all this, citizens committees were idealized in many aspects. Their impact on public safety was especially exaggerated. The well-known journalist Zenon Pietkiewicz described the achievements of the Main Citizens Committee in Łódź in the following way: "In the plague of disasters which our country, which became an area of bloody war efforts, experienced, we witness a very significant phenomenon which is worthy of special attention.

[...] This change to the organization of public safety was firstly regarded with fear. It was supposed that all dark powers and social lowlifes would break out and Lódź, which, of all our cities, has the biggest number of them, would be exposed to bandits and gangs.

Yet something strange, even wonderful, happened. The scum neither crawled out or attacked streets, shops and houses, but completely disappeared. An odd calm prevailed in the city, and women and children could walk without care on the streets and in dangerous suburbia, which had usually been full of suspicious individuals and bandits in the dark night" 44 .

40 Opał dla Warszawy, "Kurier Warszawski", September 16, 1914, No. 256; Sprawy żywnościowe $i$ opałowe, "Kurier Warszawski", December 5, 1914, No. 336; Opat, światło, woda, tramwaje, "Kurier Warszawski", December 10, 1914, No. 341; Miasto a opat, "Kurier Warszawski", May 27, 1915, No. 144. See: K. Sierakowska, op. cit., pp. 216-232.

${ }^{41}$ R.E. Blobau m, A Minor Apocalypse..., p. 105.

42 Tułacze, "Kurier Warszawski", November 4, 1914, No. 274; Bezdomni, "Kurier Warszawski", November 10, 1914, No. 284; Ewakuacja bezdomnych, "Kurier Warszawski", November 26, 1914, No. 327.

${ }^{43}$ R.E. Blobaum, A Warsaw Story: Polish-Jewish Relation during the First World War, [in:] Warsaw. The Jewish Metropolis. Essays in Honor of the $75^{\text {th }}$ Birthday of Professor Antony Polonsky, Leiden-Boston 2015, pp. 271-298.

${ }^{44}$ Próba sił społecznych, "Kurier Warszawski", September 28, 1914, No. 268. 
At the beginning of 1915 article titled Institutions that should stay. declared that citizens committees contributed to a number of useful enterprises that reshaped the social map of Polish cities - including Warsaw: "Due to this aroused vigor among the citizens and the extraordinary conditions which allow some freedom of action we have not only almshouses for homeless people, cookhouses for intelligentsia and lazar houses. We also have a job market, which our industry has urgently needed for at least the last 25 years. We have a few hundred new nurseries and schools in Warsaw, which was condemned by one of our activists as a "city of illiterates". We finally have a citizen sanitary organization, which has started - actually 50 years too late - the energetic and skillful fight with factors of public health.

Can you imagine, dear readers, that all these institutions, created during wartime and only due to war could be closed and dissolved as soon as the strenuous, diplomatic negotiations over the terms of a lasting peace and changes to the state borders start? $[\ldots]$ Asking this questions gives us the answer and also prejudges them" ${ }^{45}$.

Surprisingly, when urban society in the Kingdom of Poland managed to organize itself under the system of citizens committees, on March 17, 1915 the tsarist government decided to introduce the Russian law of urban self-government in Russian Poland.

\section{Troublesome self-governments and high hopes}

After the introduction of municipalities in the Kingdom of Poland was declared, "Kurier Warszawski" commented: "in a few months our society will finally have important room to act. We are waiting for this moment with concern. We cannot hide that we have unlearned how to run our own country". Despite these circumstances, the future was seemed to be optimistic: "where it was possible, Poles achieved a lot in the field of self-government". It was believed that under the rules of the self-government Lwow and Cracow became places with the "high culture", with the "excellent municipal economic, social and cultural institutions. What was important, it happened "under very limited financial conditions!" The conclusion could be the only one "we believe that the Kingdom of Poland

${ }^{45}$ Instytucje, które powinny zostać, "Kurier Warszawski”, January 26, 1915, No. 26. 
will also obtain a great deal of practical sense, citizen vigor and understanding of culture"46.

However, public opinion was dissatisfied with the simple application of laws known from internal parts of the Tsarist Empire, as it was believed (from 1905) that the Kingdom of Poland needed special solutions that were suitable for the ethnic and social composition of cities and towns in Russian Poland. Although the political decision from March 1915 guaranteed that Polish could be an official language used in the new councils (which had been blocked during debates in Duma and Council of State before the war) it was still obvious than the new law would not be warmly welcomed by Poles: "it is no secret for anyone that urban self-government in the form passed by the Duma could not satisfy our society even in an epoch of great depression in expectations and politics of small successes. [...] However, if we look from the point of view of immediate social needs, we are convinced that our society will appreciate this temporary reform and do everything to use it skillfully and zealously"47.

"Tygodnik Ilustrowany", Poland's biggest cultural magazine, also noted that "urban reform is probably provisional and intended to realize some economic and social tasks which were always urgent, but have now become burning"48. This ambivalent approach was dominant. The proposed self-government was criticized because of its undemocratic system of voting and unclear range of competences ${ }^{49}$. Many Polish leading politicians and intellectuals - like Aleksander Świętochowski, Władysław Grabski and Roman Dmowski - were convinced that the planned urban self-government should be understood only as temporary solution until serious reforms were prepared ${ }^{50}$.

Nevertheless, the scale of negligence was so high that particular groups of interests and individuals designed what should be done by elected councils ${ }^{51}$. Clerks of Warsaw's Magistrat, interviewed

46 Wprowadzenie samorząu, "Kurier Warszawski”, April 6, 1915, No. 94.

47 Ibidem.

48 Samorzą miejski $w$ Królestwie Polskim, "Tygodnik Ilustrowany" 1915, No. 16 , p. 242.

49 W sprawie samorzadu miejskiego, "Kurier Warszawski”, April 13, 1915, No. 101.

50 Samorzą miejski $w$ Królestwie Polskim, "Tygodnik Ilustrowany" 1915, No. 18, pp. 275-276; No. 19, p. 292; No. 24, p. 373.

${ }^{11}$ Samorzad a zdrowie publiczne, "Kurier Warszawski", June 7, 1915, No. 155; Samorzad a estetyka, "Kurier Warszawski", May 28, 1915, No. 145; Samorzad 
by "Tygodnik Illustrowany", revealed how many things the new self-government would have to do and how bad the economic condition of the city was ${ }^{52}$. Warsaw's press campaigned for the active attendance of professionals with a vast knowledge about urban life in the projected self-government ${ }^{53}$. Moreover, it was believed that "self-government is even more important for the province that Warsaw", so should be treated as an important national interest ${ }^{54}$.

One of the biggest challenges was the reconstruction of damaged towns once the war had ended. Hygienists proposed seizing the opportunity to build new districts as "garden cities", which could be a good entry point for the more ambitious social reforms which they had been fighting for many years ${ }^{55}$. Another idea was formulated by artists and architects, who wanted to develop a national style for new Polish cities. Actually, this debate was typical for Eastern and Central Europe, where searching for a "national style" in culture became a common theme ${ }^{56}$. They intended to strengthen the "Polishness" of cities and towns and diminish Jewish and German influences on their architecture ${ }^{57}$.

Although wartime seems to be the worst time to publish theoretical works, increased interest in the topic of urban policy and self-government resulted in a number of interesting books being published in Warsaw in 1914 and 1915. "Tygodnik Ilustrowany" even prepared a bibliography of all the Polish books about urban reform and contemporary conditions ${ }^{58}$. What was characteristic for these works was the fact that their authors strongly supported a modern, active form of urban policy known from Western Europe. From this point of view even the experiences of urban self-government from Russia or Galicia were treated as backward, even if they generally appreciated the results.

miejski w Królestwie Polskim, “Tygodnik Ilustrowany" 1915, No. 22, p. 340; No. 23, p. 357.

52 “Tygodnik Ilustrowany” 1915, No. 26, p. 406.

53 Pierwsze kroki, "Kurier Warszawski”, April 12, 1915, No. 100.

54 "Tygodnik Ilustrowany" 1915, No. 21, p. 324.

55 Jak odbudować siedziby nasze, "Kurier Warszawski", February 6, 1915, No. 37.

${ }^{56}$ A. Moravans zky, Competing Visions: Aesthetic Invention and Social Imagination in Central European Architecture 1867-1918, Cambridge, Mass. 1998, pp. 217-284.

${ }^{57}$ Odbudowa miast, "Kurier Warszawski”, April 27, 1915, No. 115; Odbudowa miast i miasteczek, "Kurier Warszawski”, July 12, 1915, No. 190.

58 Z literatury o samorzadzie, "Tygodnik Ilustrowany" 1915, No. 20, p. 316; No. 22, p. 348 ; No. 23, p. 364; No. 24, p. 380 ; No. 27, p. 428. 
The well-known economist and journalists Stanisław Koszutski handed out a book entitled "Our cities and self-government", which was mainly a ruthless critique of the tsarist administration and, additionally, an interesting analysis of the new law and its possible results ${ }^{59}$. For Koszutski it was obvious that the postwar reconstruction of ruined provincial towns should be the most important task of local governments ${ }^{60}$. Obviously, he was aware of the limitations and disadvantages of the self-government proposed by the tsar. However, he believed that even in places where municipal governments were far from being faultless, the number of pros was much greater than the number of cons. As an example, Koszutski highlighted Lviv, which had achieved self-government in 1870: "In 1850 the economy of Lviv was very sad as a result of the most widespread bureaucratic governance. Empty budget, sell out goods, forests roughly cut down, estates falling into ruin this was the image of that economy. Lviv, like the whole of Galicia, had been neglected and exploited by the German bureaucratic administration. It became demoted to a backwater. When self-government was introduced, pavements and sidewalks were bad, there were no parks and squares, city lighting was extremely poor. Lviv had gone without well-managed transportation, hygienic conditions were unfavorable, streets were not properly planned, no one took care of the city esthetics. Not to mention the complete negligence of schools and education and ignoring the cultural, social and national needs of inhabitants. Twenty five years of self-government was enough for the city to recover from its fall and make Lviv a properly-organized, big city, with an attractive, beautiful appeal, and finally, to make the city a first-class educational and cultural center"61.

Koszutski was one of those Polish writers who understood clearly the organization of municipal self-government in Western Europe and its great achievements. However, he decided to use the example of Lviv because he was aware that Polish cities could not be compared to Western European under such local conditions. However, Lviv became an example of successful self-government for one more reason: along with Cracow it was the most recognized

${ }^{59}$ S. Koszutski, Nasze miasta a samorzą (życie miast $w$ Królestwie Polskim i reforma samorzadowa), Warszawa-Lwów 1915.

60 Ibidem, p. 77.

${ }^{61}$ Ibidem, pp. 36-37. 
example of a city governed by Poles ${ }^{62}$. So, Koszutski's arguments should be read as evidence of the importance of municipal government understood as a national matter among the leaders of public opinion in the Kingdom of Poland during the first stage of the Great War. Self-government, even though imperfect, was regarded as a wonderful opportunity to satisfy both economic and national needs.

While Koszutski's vision of self-government can be described as "moderately progressive", for Edward Strasburger, an economist from Jagiellonian University (who published his first Polish theoretical book about urban policy in Warsaw in 1915), elected city councils should realize far more ambitious goals ${ }^{63}$. Unlike Koszutski, Strasburger identified the problems of urban self-government and its scope of authority mostly as an economic, not national, matter. He divided the tasks of the municipality into administrative, social and economic. It was out of question for urban self-government to have many social responsibilities and the urban poor should be the recipient of these policies, whereas education, housing problems or health were understood as typical forms of municipal activity that could not be done well by the state: "In particular, I call that activity of the municipality "social" which is intended to reduce and soften inequality in income distribution between different social strata, caused by the contemporary individualistic economic order.

In the strict sense, the social tasks of the municipality are helping the poor in order to upgrade them into a higher level of culture and welfare.

[...] In modern great cities income differences intensified. With the development of great industry a class of capital, means of production and real estate owners in a city emerged. On the other hand we can notice migrant people who are searching for higher salaries in a city and often cannot find them. Those landless peasants, small craftsmen, all people with limited needs who are increasing work supply. In the case of an economic crisis they become a reserve army without jobs, reducing earnings. They consist

${ }^{62}$ Tensions between Poles, Jews and Ukrainians were a serious problem in the Lviv City Council. See: Ł.T. S roka, Rada Miejska we Lwowie w okresie autonomii galicyjskiej 1870-1914. Studium o elicie władzy, Kraków 2012.

${ }^{63}$ E. Stras burger, Wielkomiejska polityka społeczno-gospodarcza. Ze szczególnym uwzględnieniem miast w Anglii i Niemczech, Warszawa 1915. 
of a strata of poor people with a low level of culture and ethics. The municipality has a duty to ease those blatant inequalities, even partly"64.

Strasburger, inspired by Western (mostly English) practices, proposed a "municipal socialism", understood as a system where self-government not only attempts to satisfy social needs, but also runs its own enterprises, intended to reduce the cost of services like transportation, water, gas and energy ${ }^{65}$. At the turn of the $20^{\text {th }}$ century municipal enterprises were a vanguard of modern urban policy, whose introduction was often considered as a "too far-reaching intervention" of self-government into the market-based economic order. On the other hand, the risk of revolutions or riots and the increasing political power of progressivists and socialists in Europe, meant that prior to the Great War city councils were more and more inclined to use radical policies to reduce social unrest. Polish authors generally dreamed of a "moderate" vision of municipality, based on the experiences of Western Europe, where urban self-government had been considered an obvious solution for many years. However, the situation of the Kingdom of Poland was so dramatic that experiments like "municipal socialism" seemed to be justified. For Strasburger, Łódź seemed to be an illustration: "The economy of Łódź is a blatant example of the Manchester rule (laissez-faire approach to economy - K.Ś.) in city management. The city administration is careless about its development. Suffice it to say that Łódź still does not have water supply and sewage, although it has half a million inhabitants. Private initiatives have undertaken to run profitable companies like trams or city lighting. Social policy is completely neglected. Łódź is a typical place where the city administration holds onto individualistic course of nonintervention in private economic relations. There is only one direction in which local and state governments intervene - obstruction of meeting of the most important needs of inhabitants. An administration like that has resulted in unfortunate effects"66.

64 Ibidem, p. 8.

${ }^{65}$ For the concept of "municipal socialism" in Europe see: J. Sheldrake, Municipal Socialism, Aldershot 1989; S.D. Pennybacker, A Vision For London 1889-1914: Labour, Everyday Life and the LCC Experiment, London-New York 1995; U. Kueh1, Der Munizipalsozialismus in Europa. Le socialisme municipal en Europe, Muenchen 2001.

${ }^{66}$ E. Strasburger, op. cit., p. 45. 
In the late spring of 1915 everything pointed to the fact that the urban society of the Kingdom of Poland, satisfied with results of its citizens committees' work, were getting ready for urban self-government - even if its planned version was not as beneficial as public opinion had demanded. On June 22 Kurier Warszawski informed their readership about the projected trip of "urban activists" from Warsaw to St. Petersburg, Moscow, Vilnius and Kyiv, where the law planned for the Kingdom of Poland had been in force for many years ${ }^{67}$. Unfortunately, the trip never happened as the Germans took Warsaw on August 5, 1915. By the end of 1915 all territory of the Kingdom of Poland was occupied by German troops. Citizens committees were dissolved with the exception of Warsaw's, which existed until 1916. As a result, Russian urban self-government in the Kingdom of Poland never became a reality. However, it turned out that the battle for urban self-government in the Kingdom of Poland has not yet been lost.

\section{Wartime urban politics}

Authors writing about the German and Austro-Hungarian occupation of Poland must face the ambivalence caused by the difference between its detrimental political effects and positive political effects $^{68}$. From 1915 to 1918 the politics of the Central Powers became a key factor in the changes and state-forming processes that happened across a huge area of Central Eastern Europe. As Arkadiusz Stempin pointed out, during the First World War especially Germany intended to be the "moral conquestor" of Poland and other countries in the Eastern Europe ${ }^{69}$. While building their concept of Mitteleuropa, they became for better or for worse the great builders and great destructors of the region ${ }^{70}$. All institutions created during the wartime in the German-occupied parts of Poland, Ukraine, Belarus and Baltic states should be regarded as a legacy of this long occupation, while all conflicts that happened

${ }^{67}$ Zbiorowa wycieczka działaczy miejskich, "Kurier Warszawski”, June 22, 1915, No. 170 .

${ }^{68}$ R.E. Blobau m, A Minor Apocalypse..., pp. 132-133.

${ }^{69}$ A. Ste m pin, Próba „moralnego podboju” Polski przez Cesarstwo Niemieckie w latach I wojny światowej, Warszawa 2014.

${ }^{70}$ M. Górny, Concept of Mitteleuropa, [in:] 1914-1918-online. International Encyclopedia of the First World War, https://encyclopedia.1914-1918-online.net/ article/concept_of_mitteleuropa/2015-09-18 (accessed: 18 IX 2021). 
between Central Eastern Europeans after the Great War became its bloody scars. Jesse Kauffman has called the relations between Germans and Poles during the Great War as an "illusive alliance": a temporary forced collaboration despite opposing political goals ${ }^{71}$. On the other hand, Austrian did not have so far-reaching aspirations even if the results of their rules in the occupied Kingdom of Poland were very similar to the German ones. "The current policy was shaped, apart from the actual war situation, on the one hand by the deepening dependence of the Habsburg monarchy on its stronger, German ally, but also, on the other hand, by the Austro-German rivalry around the 'Polenfrage', the necessity of agreements on many actions in the sphere of 'great politics', mutual aversion and mistrust, if not paralyzing, then at least very much slowing down joint actions towards the Kingdom of Poland"72.

One of the positive results of this situation was the introduction of urban self-governments. After one year of occupation, Germans announced general elections in Warsaw, Łódź and several cities in the Kingdom of Poland. Yet again the voting system was based on the curial system, however the elections in each curia were proportional. One difference was, however, symptomatic: new municipal governments were intended to be purely Polish, with Poles occupying most of posts of councilors and mayors. With this in mind, limitations for Jews became a common goal of both the Polish elites and German occupants. Kauffman noted: "the Polish and German elites, however, unknowingly harbored similar goals with regard to Jewish participation in the election. In the civil administration's report on the elections, Kries ${ }^{73}$ noted that Warsaw's Jews, whom he believed to be about 40 percent of population, were entitled to 'fair representation'. He also, however, wanted to preserve 'the Polish character' of the capital's city council. The chief administrator believed that the intricacies of the curial system and the proportional elections would help limit Jewish influence without blatantly excluding them"74.

${ }^{71}$ J. Kauffman, op. cit.

72 J. Lew and ow ski, Okupacja austriacka..., s. 30.

73 Wolfgang von Kries (1868-1945) was the civil Chief Administrator of the occupied Kingdom of Poland.

${ }^{74}$ J. Kauffman, op. cit., p. 127. 
Under these circumstances Polish public opinion could strongly support elections. As "Kurier Warszawski" reported: "Wide sectors of the general public in our city welcome the announcement of elections by the occupant administration because in this way the issue of urban self-government for Warsaw, which has been suspended in midair for a long time, finally is close in time. Moreover, the electoral system gives rise to the hope that the city administration will fall into hands of appropriate people with public confidence and knowledge. And this way, there will be no risky experiments in so difficult a metropolitan economy like in Warsaw, recently significantly enlarged in area and number of inhabitants. On the contrary, there it will be under a watchful eye, with an understanding of the existing economic and cultural conditions"75.

For the editors of "Kurier Warszawski", these wartime elections were an extraordinary event which required national consent. Future self-government was imagined as an expert body leading moderate politics. Councilors should be elected from "the best candidates", which meant people with the highest level of knowledge about the city and excellent administrative skills: "The municipality has many specific economic, cultural and - to a certain extent social tasks to achieve. So only the people who understand this job (which is difficult here) or who have a natural ability to do so, a professional theoretical or practical education should be elected. In other words, we have to elect people in whom we trust that they can work in local administration, understand their great responsibility and the time necessary to meet the obligations.

[...] We do not want politicians in Warsaw's municipality. We demand that the city administration should be in the hands of those who are brave, skilled and who have minimum of spare time. We are convinced that when this happens, the elections will became popular and all people entitled to vote will take part in them - with a successful result"76.

If the conservative "Kurier Warszawski" was afraid of these "risky experiments", Stanisław Aleksander Kempner, chief editor of the liberal "Nowa Gazeta" was aware of the extraordinary status of the wartime elections. In his words, "wartime means some additional duties for the municipality. We have to reckon with inevitable

75 Samorzad $w$ Warszawie, "Kurier Warszawski”, May 15, 1916, No. 134.

76 Pod hasłem „najlepszych”, “Kurier Warszawski”, June 6, 1916, No. 156. 
troubles and shortages in different aspects of life". However, despite wartime conditions, he was convinced that Warsaw's municipality would have to carry out many ambitious tasks: "Of course, it is a program of social reform above all else. Municipalization of all general interest industries and development of these that are already municipal, care of municipal schools, community colleges, opening of social museums, developing suburbia to the metropolitan level, improvement of sanitary conditions, supervision of shelters for infants, children, hospitals, progressive philanthropy with regular paid employment, housing for workers and so on and so on - these are just a few of the main activities of self-government. Altogether, it should build a national existence and be focused on the whole cultural and democratic homeland. The capital city should be the grand model for all Poland. Warsaw must be the place where spirits of great tolerance, common equality, unity and truly Polish culture meet" 77 .

What was characteristic, even for Kempner, was that the national aspect of urban self-government was just as important as this whole litany of things to do. "First of all - he argued - the future city council will have the grateful, but difficult duty of eliminating the external features of Moskiewszczyzna (Russian influences in architecture) from Warsaw, reconstructing the Polish character of the city and initiating the strenuous task of increasing the capital's level of culture"78.

Consequently, "Nowa Gazeta" perceived self-government and the associated municipal elections as purely political. The newspaper strongly criticized Endecja's concept of a consolidated national list of candidates ${ }^{79}$. As the voting system in each curia was proportional, liberals strongly believed that only open choice between different visions and programs was worth considering. They supported the central committee created in Warsaw by democratic powers - while nationalist created their own committee. Of course, "Nowa Gazeta" had a contrasting opinion on who should be elected to "Kurier Warszawski": "City councilors should not be sought only among the best and the most recognized social activists or those people engaged in liberal professions. In particular, the curia system guarantees cooperation between people with a high position. We

77 S.A. Kempner, Gospodarcze zadania rady miejskiej, "Nowa Gazeta", June 25, 1916, No. 286.

${ }^{78}$ Ibidem.

${ }^{79}$ See: K. Zieliński, op. cit., pp. 258-270. 
need to finally turn around this old manner of self-appointment, which was hidden by elections so many time and which sometimes masked the elections. We need to reduce the number of men entitled by birth or social advances. We also need to break up and dilute groups who achieved power and do not wish to lose it and who are always laying claim to power by creating ad hoc "nonpartisan parties". These are crypto-political but biased coteries" 80 .

The most radical vision of municipality was presented by the socialists, who decided to take part in the election despite the electing system reducing their chances only to the sixth curia - consisting of workers. Aleksy Rżewski, leader of the Polish Socialist Party in Łódź (and later the first mayor of Łódź in the truly democratic elections of 1919), published in the local press a sort of political manifesto: "Our first demand is jobs for the unemployed. Polish workers have no aversion to work, so when public works like the building of roads and reconstruction of damaged towns are launched, Polish workers will not shirk their responsibility. But for those who cannot work, the municipality must open cheap diners, it has to take care of the poor children that cannot be fed by their parents.

Broad masses are under the weight of exploitation, usury and food speculation.

Representatives of workers in the city council have to demand the municipalization of private companies, bakeries, groceries - the city must take the sale of coal and fuel into its own hands. The city council has to take control of companies such as gas works and power stations to provide light and heat after whole day of hard work.

The city council, which is watching over the health of the city, has to build hospitals and asylums. Everyone should find care and medical aid. Sanitation of the city, hygienic improvements in suburbia and workers districts is one of the most important tasks of the municipal economy.

[...] Common and free of charge elementary education in municipal schools will raise our youth out of their deep ignorance. [...] This will be done by the members of the representatives of workers, who will force city councils to enter onto the path of emancipation and democracy" 81 .

80 Wybory, "Nowa Gazeta", June 18, 1916, No. 276.

81 Wyzwolenie robotników, "Nowy Kurier Łódzki”, January 6, 1917, No. 5. 
In Warsaw, nationalists and democrats finally signed the agreement, which was then supported by local Jewry ${ }^{82}$. As a result, the election was peaceful: "Tygodnik Ilustrowany" reported that only the election in the sixth curia - formed of workers - provoked intensive political campaign ${ }^{83}$. Many authors and activists who took part in the debates between 1914 and 1915 became councilors. For instance, Prince Lubomirski, former leader of Warsaw Citizens Committee, became the mayor of Warsaw in 1916. Also Adolf Suligowski ${ }^{84}$, the most recognized Polish author on urban issues at the time, became a counselor, as well as hygienist Józef Zawadzki and well-known journalists Bolesław Koskowski, Wacław Łypacewicz, Wacław Sieroszewski and Ludomir Grendyszyński ${ }^{85}$.

In the autumn of 1916 cities of the Kingdom of Poland became self-governmental for the first time since the $1860 \mathrm{~s}^{86}$. The only exception was Łódź, where elections were held in January of 1917. In contrast to Warsaw, the impact of socialists here was much more important and there was no agreement between Poles and Jews, leading to an emotional campaign. Nowy Kurjer Łódzki was afraid that the city council would be dominated by Jews, whose "number of voters was completely disproportionate to the real number of the Jewish population in Łódž" ${ }^{7}$. The newly elected council eventually consisted of 27 Poles, 25 Jews and 8 Germans $^{88}$. While the municipal government of Warsaw was conservative and bourgeois, the city council of Łódź was politically much more varied, which should be interpreted as result of different social composition of these two

${ }^{82}$ Akt pojednawczy, "Nowa Gazeta", July 1, 1916, No. 295.

${ }^{83}$ Epilog wyborów do rady miejskiej, "Tygodnik Ilustrowany”, July 22, 1917, No. 30, p. 358.

${ }^{84}$ Suligowski published all his works on urban policy from the 1890s to the Great War just before the elections: A. Suligow s ki, Pisma Adolfa Suligowskiego, vol. I (Potrzeba samorzadu), Warszawa 1915; idem, Pisma Adolfa Suligowskiego, vol. II (Kwestie miejskie), Warszawa 1915.

85 Sprawozdanie $z$ działaności rady $m$. stołecznego Warszawy za okres czasu od 24 lipca 1916 r. do 31 grudnia 1916 r., Warszawa 1917, pp. 1-3.

${ }^{86} \mathrm{~J}$. Wasiak, Kształtowanie sie samorzadu miejskiego $w$ Polsce centralnej $w$ latach 1915-1926, "Acta Universitatis Lodziensis. Folia Historica" 1980, issue 1, pp. 51-59; G. Gór s ki, Odbudowa polskiej administracji publicznej w latach 1916-1919, “Czasy Nowożytne” 1998, vol. V, pp. 29-37; J.Z. Pająk, Powstanie $i$ rozwój samorzadu $w$ miastach Królestwa Polskiego podczas I wojny światowej, [in:] Z historii ustroju państwa polskiego od XIV do XX wieku, Kielce 2003, pp. 103-114.

87 Sytuacja przedwyborcza, "Nowy Kurier Łódzki”, January 12, 1917, No. 10.

88 A. Stawiszyńska, op. cit., pp. 663-675. 
cities and the different number of an unsolved needs in local urban economics. This makes the case of Łódź seem a bit more interesting than the much more known case of Warsaw.

\section{Conclusion}

Robert Blobaum warns against idealizing the wartime efforts in Warsaw as a success story. In his opinion: "Ultimately, management of Warsaw's war time social and economic crisis was bound to fail, as the Warsaw Citizens Committee and its successors lost the race against impending catastrophe. Reasons for that failure are not difficult to determine, though certainly the consequences may have been less socially divisive. The administration of public assistance could have been more democratic, its organization more efficient, its distribution more prejudicial, its corruption better contained. Funds could have been diverted from political and cultural projects of "national” significance to those of far more immediate and crucial social need. Yet even under these imagined circumstances, Warsaw's war time crisis was beyond manageable due to other more important factors" $"$.

Without doubt, wartime was a catastrophe for cities in Poland, which had to cope with military destruction, a great number of refugees, hunger, shortages and economic robbery by its German occupants. Although the capital Warsaw managed to recover after the Great War, ransacked Łódź, which lost its Russian market, never rebuilt its huge economic power. The urban discourse created in the Kingdom of Poland during the war is, nevertheless, a discourse of mobilization and hope, not one of hand-wringing.

When the pre-war style of urban governance became outdated, new models and legal frameworks of urban policy had to be developed in the reality of a military and temporary administration. The experience of citizens committees preparing for urban self-government had a significant impact on urban policy in independent Poland after 1918. It was also an important school for making the urban problems and urban discourse truly political and focused on real differences. Visions of the future development of Polish cities created during the Great War can be divided into radically modernistic (municipal socialism) and national (bourgeois). The rivalry between them, revealed before the municipal elections in 1916,

${ }^{89}$ R.E. Blobaum, A Minor Apocalypse..., p. 131. 
heralded conflicts which determined urban politics in Poland after the World War One. After all, these visions were themselves obviously modern ${ }^{90}$.

From the Central and East European perspective, it is worth underlining that at the beginning of 1917, when Polish cities achieved urban self-government, the Eastern Front stretched from Estonia to Moldova and huge parts of contemporary Ukraine or Belarus still remained under the rule of the Russian tsar. For them the occupation of the Central Powers and the creation of national and municipal institutions were yet to come. Therefore, the case of Poland during the Great War can be understood both as the vanguard of the common experience of the whole region and a specific story with its own logic.

\section{Bibliography}

\section{Printed sources}

Gorski S., Niemcy w Królestwie Polskim, Warszawa 1911.

Koszutski S., Nasze miasta a samorzad (życie miast $w$ Królestwie Polskim i reforma samorzadowa). Warszawa-Lwów 1915.

Sprawozdanie $z$ działalności rady $m$. stołecznego Warszawy za okres czasu od 24 lipca 1916 r. do 31 grudnia 1916 r., Warszawa 1917.

Strasburger E., Wielkomiejska polityka społeczno-gospodarcza. Ze szczególnym uwzglednieniem miast $w$ Anglii i Niemczech, Warszawa 1915.

Suligowski A., Pisma Adolfa Suligowskiego, vol. I (Potrzeba samorzadu), Warszawa 1915.

Suligowski A., Pisma Adolfa Suligowskiego, vol. II (Kwestie miejskie), Warszawa 1915.

\section{Press}

"Kurier Warszawski" 1914-1918.

"Nowa Gazeta" 1914-1918.

“Nowy Kurier Łódzki” 1914-1918.

“Tygodnik Ilustrowany” 1914-1918.

"Zdrowie" 1917.

90 See the Kamil Piskała's chapter of: A. Zysiak et al., From Cotton and Smoke. Eódź - Industrial City and Discourses of Asynchronous Modernity 18971994, Łódź-Kraków 2018, pp. 101-159. 


\section{STudies}

Blobaum R.E., A Minor Apocalypse: Warsaw during the First World War, New York 2017.

Blobaum R.E., A Warsaw Story: Polish-Jewish Relation during the First World War, [in:] Warsaw. The Jewish Metropolis. Essays in Honor of the $75^{\text {th }}$ Birthday of Professor Antony Polonsky, Leiden-Boston 2015, pp. 271-298.

Blobaum R.E., Rewolucja: Russian Poland 1904-1907, Ithaca-London 1995.

Blobaum R.E., The Politics of Antisemitism in Fin-de-Siècle Warsaw, "The Journal of Modern History" 2001, vol. LXXIII, No. 2, pp. 275-306.

Borodziej W., Górny M., Nasza wojna, vol. I (Imperia 1912-1916), Warszawa 2014.

Chwalba A., Wielka Wojna Polaków 1914-1918, Warszawa 2018.

Górski G., Odbudowa polskiej administracji publicznej w latach 1916-1919, “Czasy Nowożytne” 1998, vol. V, pp. 29-37.

Imperia, Narody i Społeczeństwa Europy Wschodniej i Środkowej, na progu Pierwszej Wojny Światowej, ed. A. Nowak, Warszawa 2016.

Karwacki W.L., Łódź w latach rewolucji 1905-1907, Łódź 1975.

Kauffman J., Elusive Alliance: The German Occupation of Poland in World War I, Cambridge, Mass. 2015.

Kiepurska H., Warszawa w rewolucji 1905-1907, Warszawa 1974.

Krzywiec G., Polska bez Żydów. Studia z dziejów idei, wyobrażeń i praktyk antysemickich na ziemiach polskich poczatku XX wieku, Warszawa 2017.

Krzywiec G., Szowinizm po polsku. Przypadek Romana Dmowskiego (1886-1905), Warszawa 2009.

Krzywiec G., Z taka rewolucja musimy walczyć na noże: rewolucja $1905 \mathrm{z}$ perspektywy polskiej prawicy, [in:] Rewolucja 1905. Przewodnik „Krytyki Politycznej”, red. K. Piskała, W. Marzec, Warszawa 2013, pp. 328-533.

Kuehl U., Der Munizipalsozialismus in Europa. Le socialisme municipal en Europe. Muenchen 2001.

Lewandowski J., Okupacja austriacka w Królestwie Polskim (1914-1918), “Dzieje Najnowsze" 1998, vol. XXX, pp. 29-42.

Łupienko A., Some Remarks on the Birth of Modern City Planning in the Polish Territories (1850-1914): The Impact of the Hygienic Movement, "Mesto a Dejiny" 2016, No. 2, pp. 18-34.

Marzec W., Rebelia i reakcja. Rewolucja 1905 roku i plebejskie doświadczenie polityczne. Horyzonty nowoczesności: teoria - literatura - kultura, Łódź-Kraków 2016.

Marzec W., Śmiechowski K., Pathogenesis of the Polish Public Sphere. The Intelligentsia and Popular Unrest during and after the 1905 Revolution, "Polish Sociological Review" 2016, No. 4, pp. 437-457.

Moravanszky A., Competing Visions: Aesthetic Invention and Social Imagination in Central European Architecture 1867-1918, Cambridge, Mass. 1998.

Nalewajko-Kulikov J., Myśli nowoczesnych Żydów. Wybory do IV Dumy, bojkot ekonomiczny $i$ stosunki polsko-żydowskie (1912-1914) w świetle warszawskiego „Hajntu”, “Kwartalnik Historii Żydów” 2016, No. 2, pp. 279-299. 
Nietyksza M., Rozwój miast i aglomeracji miejsko-przemysłowych $w$ Królestwie Polskim: 1865-1914, Warszawa 1986.

Pająk J.Z., Powstanie i rozwój samorządu w miastach Królestwa Polskiego podczas I wojny światowej, [in:] Z historii ustroju państwa polskiego od XIV do XX wieku, Kielce 2003, pp. 103-114.

Pennybacker S.D., A Vision For London 1889-1914: Labour, Everyday Life and the LCC Experiment, London-New York 1995.

Petrone K., The Great War in Russian Memory, Bloomington-Indianapolis 2011.

Piasta A., Powstanie i zarys działalności Komitetu Obywatelskiego Miasta Piotrkowa 1914-1915, "Piotrkowskie Zeszyty Historyczne" 2003, vol. V, pp. 219-233.

Pierwsza niemiecka okupacja. Królestwo Polskie i kresy wschodnie pod okupacja mocarstw centralnych 1914-1918, ed. G. Kucharczyk, Warszawa 2019.

Pluvinage G., Brussels on German Time, "Cahiers Bruxellois - Brusselse Cahiers" 2014, vol. XLVI, No. 1E, pp. 15-38.

Przeniosło M., Komitet Obywatelski miasta Kielc 1914-1915, [in:] Z dziejów Kielc w latach 1914-1918, Kielce 2004, pp. 37-48.

Reconstruction and Modernization of Historic Towns in Europe in the First Half of the Twentieth Century: Nation, Politics, Society, eds I. Barańska, M. Górzyński, Kalisz 2016.

Rolf M., Imperiale Herrschaft im Weichselland: das Königreich Polen im Russischen Imperium (1864-1915), Berlin-Muenchen-Boston 2015.

Sanborn J.A., Imperial Apocalypse. The Great War and the Destruction of the Russian Empire, Oxford 2014.

Scriba A., Berlin in the 1914-1918 War, "Cahiers Bruxellois - Brusselse Cahiers" 2014, vol. XLVI, No. 1E, pp. 173-188.

Sheldrake J., Municipal Socialism, Aldershot 1989.

Sierakowska K., Śmierć, wygnanie, głów w dokumentach osobistych. Ziemie polskie w latach Wielkiej Wojny 1914-1918, Warszawa 2015.

Sroka Ł.T., Rada Miejska we Lwowie w okresie autonomii galicyjskiej 1870-1914. Studium o elicie władzy, Kraków 2012.

Stawiszyńska A., Łódź w latach I wojny światowej, Oświęcim 2016.

Stegner T., Rewolucja w opinii środowisk liberalnych Królestwa Polskiego w latach 1905-1907, [in:] Rewolucja 1905-1907 w Królestwie Polskim i w Rosji, Kielce 2005, pp. 21-43.

Stempin A., Próba „moralnego podboju” Polski przez Cesarstwo Niemieckie w latach I wojny swiatowej, Warszawa 2014.

Strupp Ch., Hamburg in the First World War, "Cahiers Bruxellois - Brusselse Cahiers" 2014, vol. XLVI, No. 1E, pp. 189-210.

Śmiechowski K., Hierarchia czy demokracja? Wizja stosunków społecznych $w$ miastach Królestwa Polskiego (na przykładzie dyskusji o samorzadzie miejskim w trakcie rewolucji 1905 roku), "Studia z Historii Społeczno-Gospodarczej XIX i XX wieku” 2015, vol. XIV, pp. 103-119. http://dx.doi.org/ $10.18778 / 2080-8313.14 .08$ 
Śmiechowski K., Kwestie miejskie. Dyskusja o problemach i przyszłości miast w Królestwie Polskim 1905-1915, Łódź 2020.

Śmiechowski K., Między rzeczywistościa biurokratyzmu a utopia samorzadu. Krytyka prasowa miejskiego aparatu urzędniczego $w$ rewolucji 1905 roku na przykładzie Łodzi, [in:] „Dusza urzędnika” - zewnętrzna akceptacja $i$ wewnętrzna niezgoda? Między irredenta a kolaboracja. Ugoda, lojalizm i legalizm, eds N. Kasparek, M. Klempert, Olsztyn 2015, pp. 105-125.

Ury S., Barricades and Banners. The Revolution of 1905 and the Transformation of Warsaw Jewry, Stanford, Ca 2012.

Vandebussche R., Lille in German Hands, "Cahiers Bruxellois - Brusselse Cahiers" 2014, vol. XLVI, No. 1E, pp. 105-119.

Wasiak J., Kształtowanie się samorzadu miejskiego $w$ Polsce centralnej $w$ latach 1915-1926, “Acta Universitatis Lodziensis. Folia Historica” 1980, issue 1, pp. 51-59.

Weeks Th.R., Fanning the Flames: Jews in the Warsaw Press 1905-1912, "East European Jewish Affairs" 1998, vol. XXVIII, No. 2, pp. 63-81.

Weeks Th.R., Nationality and Municipality: Reforming City Government in the Kingdom of Poland, 1904-1915, "Russian History" 1994, No. 1, pp. 23-47.

White J., London in the First World War, "Cahiers Bruxellois - Brusselse Cahiers" 2014, vol. XLVI, No. 1E, pp. 139-157.

Wierzchowski M., Sprawy polskie w III i IV Dumie Państwowej, Warszawa 1966.

Winter J., Robert J.-L., Capital Cities at War: Paris, London, Berlin, 1914-1919. A Cultural History, Cambridge 2007.

Zieliński K., Stosunki polsko-żydowskie na ziemiach Królestwa Polskiego w czasie pierwszej wojny światowej, Lublin 2010.

Zysiak A., Śmiechowski K., Piskała K., Marzec W., Kaźmierska K., Burski J., From Cotton and Smoke. Eódź - Industrial City and Discourses of Asynchronous Modernity 1897-1994, Łódź-Kraków 2018.

\section{NetOGRAPHY}

Górny M., Concept of Mitteleuropa, [in:] 1914-1918-online. International Encyclopedia of the First World War, Berlin, https://encyclopedia.1914-1918-online. net/article/concept_of_mitteleuropa/2015-09-18 (accessed: 18 IX 2015).

Śmiechowski K., Searching for the Better City: Urban Discourse during the Revolution of 1905 in the Kingdom of Poland, "Praktyka Teoretyczna" 2014, No. 3(13), s. 71-96, https://pressto.amu.edu.pl/index.php/prt/article/view/510/422 (accessed: 18 IX 2021). 
About the Author:

Dr Kamil Śmiechowski - historian, PhD in history of Poland, assistant professor in the Institute of History and the scientific secretary of the Interdisciplinary Center for Urban Studies, University of Łódź. Recently, he has concluded a post-doc research project on urban discourse in the Kingdom of Poland at the turn of the $20^{\text {th }}$ century, supported by the National Science Center in Poland.

Research interests: urban theory, analyses of press discourse, processes of modernization in the $19^{\text {th }}$ - and $20^{\text {th }}$-century Poland, and history of Łódź.

ㄱamil.smiechowski@filhist.uni.lodz.pl 